\title{
Healthcare and Warfare. Medical Space, Mission and Apartheid in Twentieth Century Northern Namibia
}

\author{
CATHARINA NORD* \\ Linköping University, Department of Social and Welfare Studies, ISV, National Institute for the \\ Study of Ageing and Later Life, NISAL, SE-601 74 Norrköping, Sweden
}

\begin{abstract}
In the year 1966, the first government hospital, Oshakati hospital, was inaugurated in northern South-West Africa. It was constructed by the apartheid regime of South Africa which was occupying the territory. Prior to this inauguration, Finnish missionaries had, for 65 years, provided healthcare to the indigenous people in a number of healthcare facilities of which Onandjokwe hospital was the most important. This article discusses these two agents' ideological standpoints. The same year, the war between the South-West African guerrillas and the South African state started, and continued up to 1988. The two hospitals became involved in the war; Oshakati hospital as a part of the South African war machinery, and Onandjokwe hospital as a 'terrorist hospital' in the eyes of the South Africans. The missionary Onandjokwe hospital was linked to the Lutheran church in South-West Africa, which became one of the main critics of the apartheid system early in the liberation war. Warfare and healthcare became intertwined with apartheid policies and aggression, materialised by healthcare provision based on strategic rationales rather than the people's healthcare needs. When the Namibian state took over a ruined healthcare system in 1990, the two hospitals were hubs in a healthcare landscape shaped by missionary ambitions, war and apartheid logic.
\end{abstract}

Keywords: Finnish medical mission, Apartheid, The border war, South-West Africa, Military medicine, Hospital architecture

In 1966, the first governmental hospital, Oshakati hospital, ${ }^{1}$ was inaugurated in Ovambo in present-day northern Namibia, not far from Onandjokwe hospital, run by Finnish missionaries. Although the two hospitals shared the common aim of providing the local black population with healthcare services and while close in geographical space, they were also separated by ideological distances that made them, in certain respects, absolute

* Email address for correspondence: catharina.nord@liu.se

${ }^{1}$ Intermediate Hospital Oshakati was first named Okatana State Hospital, and shortly after its inauguration this was changed to Oshakati State Hospital. Lazarus Hangula, The Oshakati Human Settlement Improvement Project: The Town of Oshakati: A Historical Background. SSD Discussion paper No. 2 (Windhoek: University of Namibia, Social Sciences Division, 1993), 20. After Namibian independence the hospital was renamed the Intermediate Hospital Oshakati. Oshakati hospital is used throughout the text for reasons of simple nomenclature. 
opposites. At the same time they were two sides of the same coin, intertwined and linked in other ways. ${ }^{2}$ The two hospitals together constituted the centre of the medical landscape that materialised over the years to come; a landscape created not only through the provision of healthcare and well-being to people according to their needs, but also by missionary Christianisation efforts, and warfare, in the form of strategic considerations and military operations. The healthcare facility provision in this area was a product of transnational exchange, international politics and apartheid. The history of hospitals and health facilities in Namibia is fragmented and unclear, in particular in the north. ${ }^{3}$ This article aims to contribute to this history, which goes back to the early twentieth century.

\section{The South African Mandate and Healthcare}

Healthcare facilities, such as hospitals, are a basic component of a healthcare infrastructure. When South-West Africa became a League of Nations C-mandate after the First World War, administered by the Union of South Africa, improved health was embedded in the mission stated in the Mandate. It was decreed that 'The Mandatory shall promote to the utmost the material and moral well-being and the social progress of the inhabitants of the territory'. ${ }^{4}$ In order to fulfil these requirements, contributions were necessary at a number of integrated welfare levels, of which the provision of healthcare was one. However, the League of Nations C-mandate did little to protect the inhabitants in South-West Africa from abuse by the colonial power, as was intended. ${ }^{5}$ South African discriminatory healthcare practices led to deteriorating health and well-being in a number of ways for the black people in South-West Africa. ${ }^{6}$ The major reason for the South African administration to develop biomedical care in South-West Africa was to sustain the labour supply of black people and to protect the health of the whites. ${ }^{7}$ The meagre provision of healthcare to black inhabitants, including low quality or total absence of healthcare infrastructure such as hospitals, was one consequence of this policy.

Hospitals were few in number when South African administration began. The German colonial authority had built a few facilities for the military as well as civilians in the southern part of the territory. ${ }^{8}$ The German military hospital in Windhoek was taken

\footnotetext{
2 The complex interconnections between colonial and missionary medicine have been elucidated in a number of works: Megan Vaughan, Curing Their Ills: Colonial Power and African Illness (Stanford, CA: Stanford University Press, 1991); Michael Jennings, 'Healing Bodies, Salvation of Souls: Missionary Medicine in Colonial Tanganyika, 1870-1939', Journal of Religion in Africa, 38, (2008), 27-56; Anna Crozier, Practising Colonial Medicine Service in British East Africa (London: I.B. Tauris, 2008), 60-1; Kathleen Vongsathorn, "First and Foremost the Evangelist"? Mission and Government Priorities for the Treatment of Leprosy in Uganda, 1927-48', Journal of Eastern African Studies, 6, 3 (2012), 544-60.

${ }^{3}$ Catharina Nord, 'The Visible Patient. Hybridity and Inpatient Ward Design in a Namibian Context' (PhD thesis: Stockholm, Royal Institute of Technology, KTH, 2003), 27.

${ }^{4}$ The League of Nations Mandate for German South-West Africa, United Nations Library, Geneva, Article 2.

${ }^{5}$ Keith Gottschalk, 'The Political Economy of Health Care: Colonial Namibia 1915-1961', Social Science and Medicine, 26, 6 (1988), 577-82: 577.

${ }^{6}$ Marion Wallace, 'Health and Society in Windhoek', Namibia, 1915-1945 (PhD thesis, University of London, Basel: Schlettwein Pub., 2002); Anthony Zwi, Shula Marks and Neil Andersson, 'Health, Apartheid and the Frontline States', Social Science and Medicine, 27, 7 (1988), 661-5; WHO, Apartheid and Health (Geneva: World Health Organization, 1987); International Defense and Aid Fund, A Nation in Peril. Health in Apartheid Namibia (London: International Defense and Aid Fund, 1985).

${ }^{7}$ Ibid., Wallace, 223.

8 Agnes van Dyk, 'The History of Nursing in Namibia' (PhD thesis, University of Namibia, Windhoek: Gamsberg Macmillan Publishers, 1997), 25.
} 
over by South Africa in $1915 .{ }^{9}$ A segregated healthcare system was already in place and South Africa continued to build on this system, aggravating the health inequalities between whites and blacks. In places of importance to the white population, such as Windhoek, Outjo, Lüderitz and Grootfontein, state-aided South African hospitals were available to whites by 1920 . Roman Catholic missionaries ran hospitals in Windhoek and Keetmanshoop for white patients. There were few healthcare options for blacks. The Roman Catholic facilities in Swakopmund and Gobabis provided segregated services to both blacks and whites. ${ }^{10}$ Biomedical care to the black population was arranged by mining companies for their labourers in Kolmanskop, Lüderitz and Tsumeb. ${ }^{11}$ Other facilities for the black population in the southern part of the territory were the Native Hospitals in Windhoek (100 beds), Keetmanshoop (18 beds), Karibib (12 beds) and Omaruru ( 8 beds). ${ }^{12}$ The Native Hospital in Windhoek was of such poor quality that black patients avoided using its services. The Location Clinic which opened in 1929 was of higher quality and was more attractive to the black population. ${ }^{13}$

Colonial space was defined through the healthcare system with the central hub of Windhoek. The District Surgeon system that was introduced after the First World War did little to alter this highly centralised system. The system provided major urban areas with a doctor while most staff resources were located in Windhoek and the mining towns. The Native Hospitals did not have permanent doctors, but were visited by the District Surgeons. ${ }^{14}$

The northern part of the territory suffered particular discrimination as regards South African healthcare provision. Only one District Surgeon was on duty in Ovambo from $1929,{ }^{15}$ although the area was the most densely populated of South-West Africa and was where approximately 40-45\% of the total population lived. In 1921, about 91000 people inhabited this very small area. The population of this region grew at great rate and in the 1960 census, maintaining its share of the total population, this number was about 230000 out of a total of 526000 inhabitants in South-West Africa. ${ }^{16}$ Whites were about $12 \% .{ }^{17}$

The people in Ovambo constituted seven groups of cattle owners and farmers living in scattered villages and farms, with similar cultures, languages and political structures. They were the Okwanyama, Ondonga, Uukwaludhii, Ongandjera, Ombalantu, Uukwambi and Uukolonkadhi (Figure 1). ${ }^{18}$ The area was managed by local leadership, kings and headmen, according to traditional land distribution rules. To South Africa, these people constituted a reserve of manpower for the growing mining industry and for other employment requirements in the south. Ovambo was the focus of South African interest as a provider of predominantly male workers. ${ }^{19}$ White farmers were encouraged to move

\footnotetext{
${ }^{9}$ Wallace, op. cit. (note 6), 118, 23.

${ }^{10}$ Wallace, op. cit. (note 6), 229-30.

11 Wallace, op. cit. (note 6), 231.

12 van Dyk, op. cit. (note 8), 43-4.

13 Wallace, op. cit. (note 6), 234, 57.

14 Wallace, op. cit. (note 6), 231-35.

15 Wallace, op. cit. (note 6), 231.

16 Report of the Commission of Enquiry into South-West Africa Affairs 1962-63 (Republic of South Africa, 1964), 37-9. (hereafter Odendaal Plan).

${ }^{17}$ Marion Wallace and John Kinahan, A History of Namibia. From the Beginning to 1990 (London: Hurst \& Co., 2011), 267.

18 Veijo Notkola and Harri Siiskonen, Fertility, Mortality and Migration in Sub-Saharan Africa. The Case of Ovamboland in North Namibia, 1925-90 (London: Macmillan Press, 2000), 33.

19 Wallace and Kinahan, op. cit. (note 17), 231.
} 


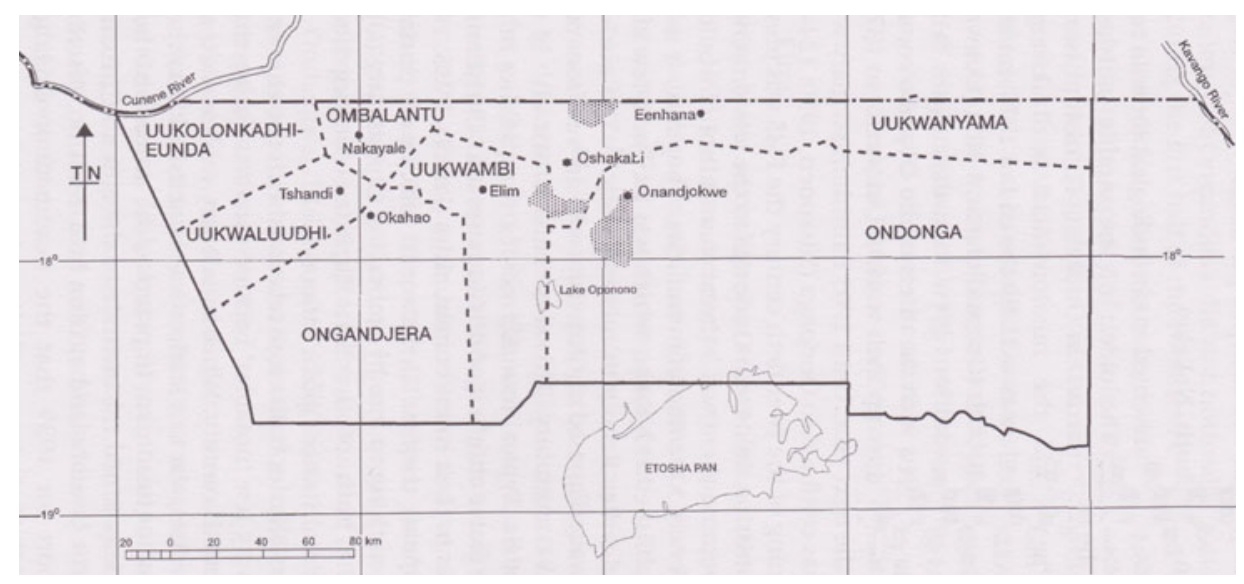

Figure 1: Map of the seven Ovambo groups. Source: Notkola and Siiskonen, (note 18), 33.

in from South Africa and settle in the vast southern territory. They were dependent on the workforce recruited as contract labourers. ${ }^{20}$ The division between the northern and southern parts of the territory was legally sanctioned during the 1920s and formally mapped off with a 'Red Line' (Figure 2). ${ }^{21}$ The South African administration in the north was small and whites were not allowed to live in the area. Most of those who did were missionaries. ${ }^{22}$ South African healthcare in the northern part of South-West Africa was to a large extent connected to the provision of manpower to the southern area. From the 1920s there were medical staff stationed in the north who were involved in the recruitment of people for labour contracts, primarily to conduct examinations and giving immunisations. ${ }^{23}$ For all other biomedical healthcare provided to the indigenous people, the South Africans relied on the missionary contributions.

\section{Missionary Medical Contribution}

At the time the Oshakati hospital was opened, three missionary societies had provided biomedical healthcare to local people for about fifty years: the Anglican Missionary Society, the Roman Catholic Society and the Finnish Missionary Society. The contribution of the Finnish missionaries was substantial, especially in Ovambo. ${ }^{24}$

In 1908, Dr Selma Rainio arrived in Ovambo from Finland. ${ }^{25}$ She joined the Finnish missionary team that had been operating in Oniipa since 1880. Her arrival meant that medical care could be provided to local people on a more professional and regular basis.

${ }^{20}$ Wallace and Kinahan, op. cit. (note 17), 221-3.

${ }^{21}$ Wallace and Kinahan, op. cit. (note 17), 229-31.

22 Carl-J. Hellberg, Mission, Colonialism and Liberation: The Lutheran Church in Namibia 1840-1966 (Windhoek: New Namibia Books, 1997), 194.

${ }^{23}$ Notkola and Siiskonen, op. cit. (note 18), 13, 106.

24 Odendaal Plan, op. cit. (note 16), 149.

25 Data on the life and work of Selma Rainio comes from the following sources unless otherwise indicated: H. Kyrönseppä, Sixty years of Finnish Medical Mission (Oniipa, Ovamboland: Finnish Missionary Society, 1965); Minnen från Kuku Selmas resa och vistelse i Ambolandet [Memories from Kuku Selma's travel and sojourn in Amboland], Memoirs of an unknown author (a long-standing colleague), Finnish Missionary Society Archive, Helsinki; Kuku Selma Rainio (1873-1939), Vanda town, http://www.vantaa.fi/ (accessed 15 March 2011). 


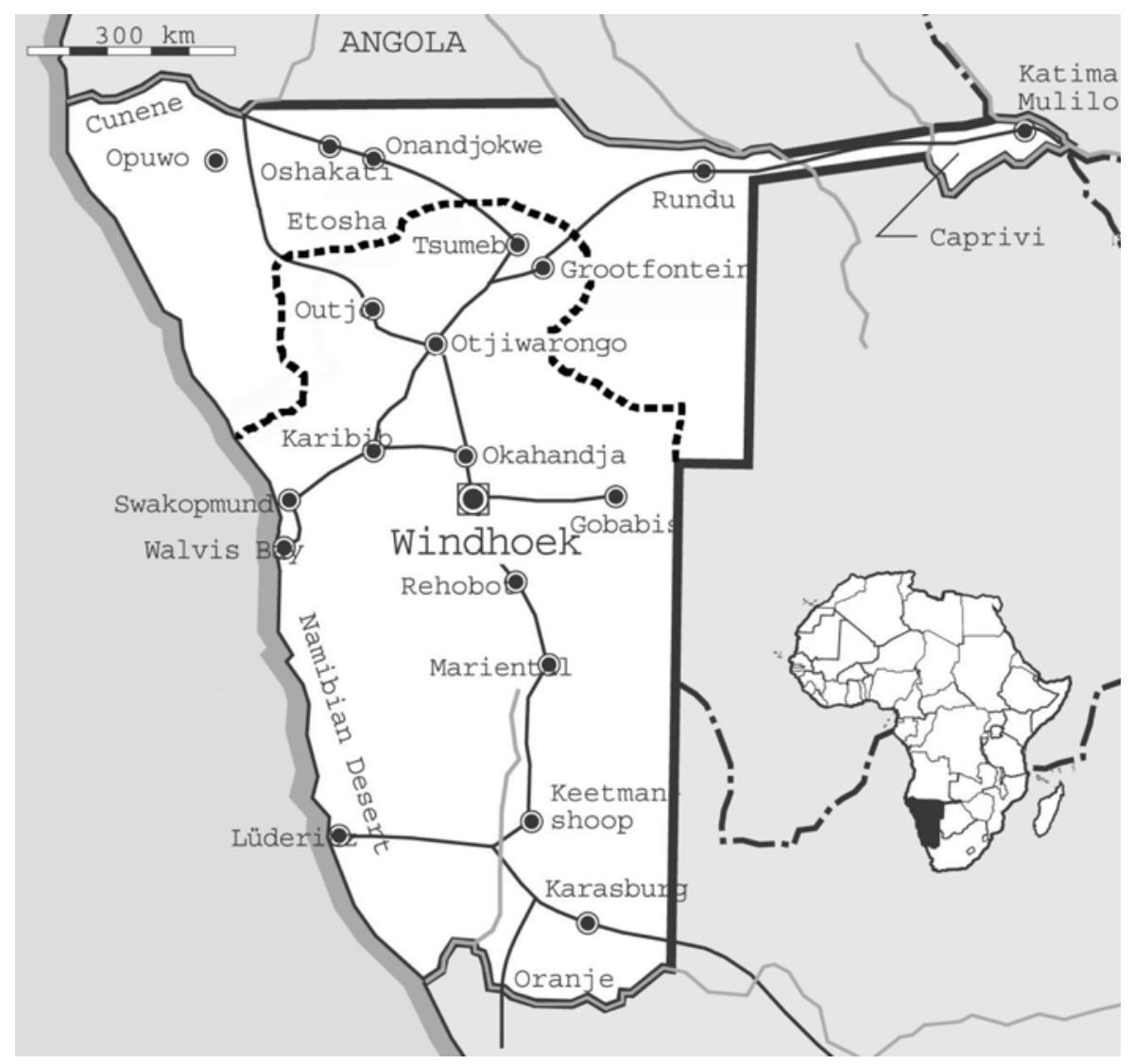

Figure 2: Map of Namibia. The dotted line indicates the border (the Red Line) between northern and southern parts in 1937. Sources: Africa Groups of Sweden (map); Wolfram Hartman et al., The Colonising Camera. Photographs in the Making of Namibian History (Cape Town: University of Cape Town Press, 1998), viii.

During her first posting, she saw outpatients in huts outside the little building where she stayed. However, the plans for the construction of proper buildings soon started.

\section{A Hospital Made of Clay}

The first building of Onandjokwe hospital was constructed of adobe bricks. It contained seven living rooms, a kitchen and a storage room for groceries. This building, which also contained an outpatient clinic and an operating room, was inaugurated on 9 July 1911. During the following decades, the hospital was extended with both smaller and larger buildings for dwelling or for healthcare purposes. Some were simple structures, such as storage rooms, workshops or sheds. Accommodation for staff and patients and a few larger buildings for medical services were finished between 1912 and $1926 .{ }^{26}$ The larger buildings had a veranda, which followed the entire length of the house with an overhanging roof giving shadow to the veranda as well as the interiors. All were clay

${ }^{26}$ Kyrönseppä, Ibid., 13-14. List of buildings in Onandjokwe hospital, year of construction and building costs specified, 1932, Collection: Selma Rainion Kokoelma, Hp XXVI, Finnish Missionary Society Archive, Helsinki. 


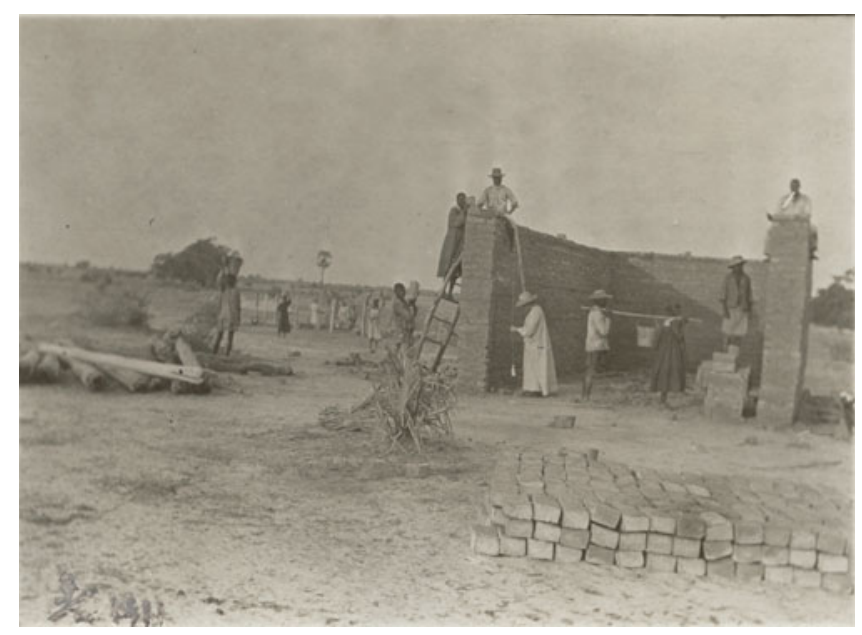

Figure 3: Selma Rainio (in the white robe and hat) measures the wall during construction work with adobe bricks performed by her colleagues in Onandjokwe. Photo: Hannu Hahti. Courtesy Kumbukumbu - Finnish Evangelical Lutheran Mission Museum.

buildings (Figure 3). The roofs, often covered with thatch, were supported by tree trunks, and provided shelter for patients waiting to be seen by the doctor. ${ }^{27}$ Much of the healthcare was provided on an outpatient basis. The Finnish nurse Karin Hirn who served at the hospital in the 1920s described the work in the booklet 'Below the Southern cross' ${ }^{28}$

'Then the treatment starts. Already in the early morning there are patients from outside. Mothers with the kiddies on their backs well tucked up in their skin bags, as well as others. Some have come from far away, others from the vicinity. The doctor examines and gives prescriptions. Very soon a big crowd is gathering outside our door. One after another they are called, examined, get their medicine and leave again., ${ }^{29}$

The hospital also had the capacity to provide inpatient care. Surgery was carried out at the hospital but that demanded a reorganisation of the few indoor spaces available. Selma Rainio writes about a male patient with an abscess in the stomach:

'A man is to be operated on but first (...) the outpatient clinic needs to be turned into a theatre (...) The nurses prepare $(. .$.$) for the surgery. If we want to use the daylight we cannot delay the operation very long since the$ afternoons in June are short.' 30

Inpatient accommodation was provided in huts erected for the purpose, where patients and accompanying family could stay (Figure 4). Karin's narration reveals that the missionaries' perceptions about local people's habits influenced how they arranged the environment for the patients:

'When the work slows down at the policlinic I go to nurse the severely ill. They lie in small round huts, with low ceilings. We have tried to arrange these in the way they do at home so that they get on better. A mother, a sister or some other relative sits and stirs a round, black claypot over the fire. The sick person lies on a straw mat. ${ }^{31}$

27 Various photos in the Finnish Missionary Museum Archive.

28 Selma Rainio, Karin Hirn and Linda Helenius, Under Söderns Kors [Below the Southern Cross] (Helsinki: Finnish Missionary Society, 1924).

${ }^{29}$ Ibid., 58-9.

${ }^{30}$ Ibid., 67.

31 Ibid., 59. 


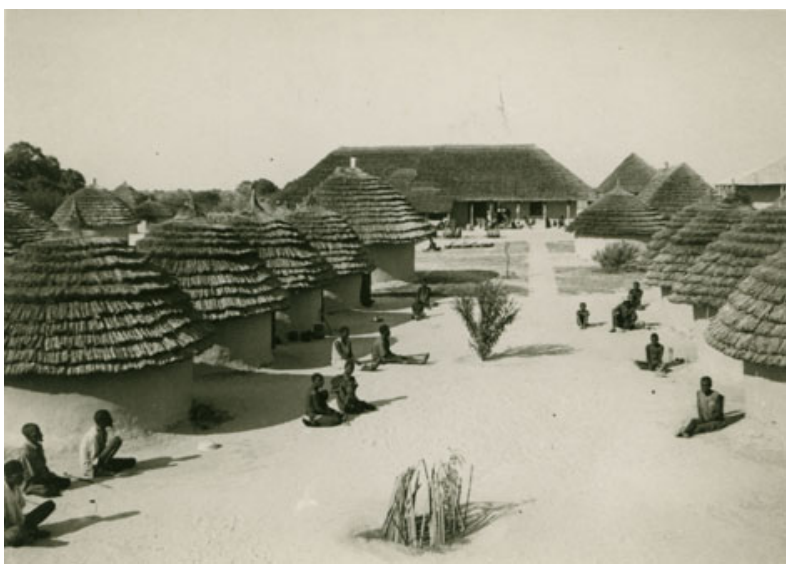

Figure 4: Huts for inpatients and accompanying relatives at Onandjokwe hospital. A larger building with thatched roof, for diagnostics and treatment, is in the background. Photo: Anni Melander. (K 1517) Courtesy of Kumbukumbu-The Finnish Evangelical Lutheran Mission Museum.

To the missionaries, medical care was not a healthcare undertaking alone but was intermixed with religious ambitions and proselytising. It was presented as a work of love, a gift to people as a sign of the passion for God. A nurse in Onandjokwe hospital expressed the missionary conviction by saying that 'the medical work blessed by God can contribute to the expansion of God's realm' ${ }^{32}$ The missionaries were primarily evangelists, and medical care had second priority. ${ }^{33}$ Healthcare was used to attract people to the Finnish missionary hospitals where they were approached with a religious aim. ${ }^{34}$ This was a successful strategy. Even people who wanted to have little to do with missionaries in general could be approached by means of medical care. ${ }^{35}$

\section{Finnish Missionary Healthcare}

Due to the success in offering healthcare, Onandjokwe hospital expanded in a continuous process. In 1932 the hospital had ' 17 rather large buildings, 49 round huts and 15 sheds' ${ }^{36}$ The hospital offered a combination of curative treatment and primary care. Common diseases that were dealt with included malaria, venereal diseases, influenza, leprosy and injuries. Malaria was rampant, especially in those years when the rains were heavy. In 1949, 40000 outpatients were treated for malaria in Onandjokwe. Vaccinations against smallpox, plague, diphtheria and poliomyelitis were carried out in campaigns during the 1940 s and 1950s. ${ }^{37}$

At the time Oshakati hospital opened, the Onandjokwe hospital had been modernised. A fire in 1958 sped up this progression. Huts and other buildings that were destroyed in the flames were replaced with new inpatient wards, a maternity ward and clinic, a ward

32 Ibid., 39.

33 Vongsathorn, op. cit. (note 2); Vaughan, op. cit. (note 2), 55-75.

${ }^{34}$ Kari Miettinen, 'On the Way to Whiteness. Christianization, Conflict and Change in Colonial Ovamboland, 1910-1965' (PhD thesis, Helsinki University, Helsinki: Suomalaisen Kirjallisuuden Seura, 2005), 91, 93-5.

35 Meredith McKittrick, To Dwell Secure: Generation, Christianity and Colonialism in Ovamboland (Portsmouth: Heinemann, 2002), 94.

${ }^{36}$ Kyrönseppä, op. cit. (note 25), 13.

${ }^{37}$ Notkola and Siiskonen, op. cit. (note 18), 105-8. 
(1) Finnish Hospital

(2) Finnish Clinic (sce numbers \& names)

- State Clinic suzervised by Finnish Mission

$\triangle \quad$ State Hospital

Siate Clinic

\section{Ovamboland}

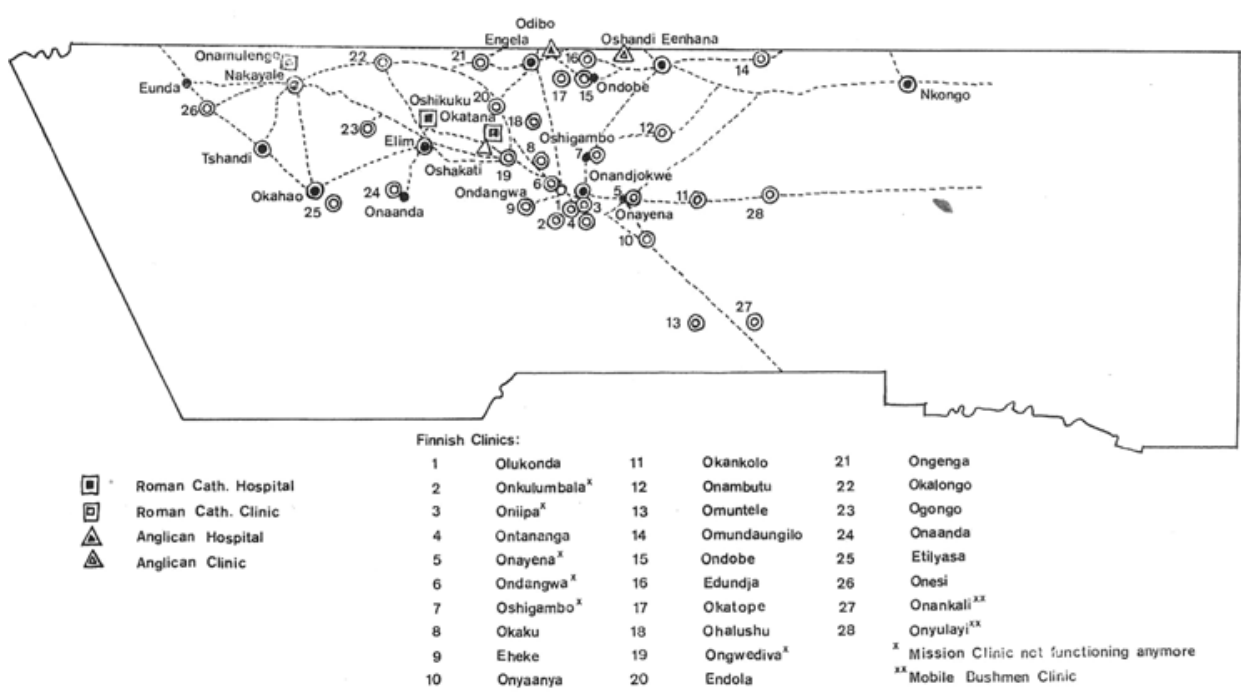

Figure 5: Map of healthcare facilities in Ovambo in the 1960s. Source: Kyrönseppä, (note 25), 2.

for infectious diseases and a tuberculosis ward. Tuberculosis was treated by the Finnish missionaries only. Late in the 1940s, Onandjokwe got an X-ray facility which could be used for diagnosing the disease. Tuberculosis patients were isolated at the hospital. ${ }^{38}$ The hospital was equipped with a new operating theatre. ${ }^{39}$ In 1963 the use of torches or the reliance on daylight during operations came to an end when the hospital received electricity. ${ }^{40}$

Finnish missionary healthcare services also started to expand in other places in Ovambo after the First World War. Over the next four decades the missionary society opened about twenty clinics and small hospitals in different places throughout Ovambo (Figure 5). They were simple buildings constructed in the same way as the Onandjokwe hospital, and often staffed by nurses. ${ }^{41}$ Physicians were in short supply. Up to the 1980 s, about ten doctors served in total on five- to six-year contracts. The majority of these were women. There was normally only one doctor in charge at any one time. From the 1960s onwards, three doctors were contracted; however, not during the war period when only one doctor staffed Onandjokwe hospital. ${ }^{42}$

The South Africans subsidised Finnish missionary healthcare from the 1930s, although irregularly. ${ }^{43}$ The missionaries were subsidised to $80 \%$ from 1962, and from 1966, to

38 Ibid., 104-9.

${ }^{39}$ Kyrönseppä, op. cit. (note 25), 17.

${ }^{40}$ Notkola and Siskonen, op. cit. (note 18), 13, 15.

${ }^{41}$ Kyrönseppä, op . cit. (note 25). Anglican and Roman Catholic missionary societies also ran healthcare facilities in the Ovambo area, albeit on a much smaller scale than the Finnish missionaries.

42 Ibid., 50. Interview with medical staff at Onandjokwe hospital.

${ }^{43}$ Kyrönseppä, op. cit. (note 25), 39. 
$100 \%{ }^{44}$ However, the contribution made by the South African government was small in relation to the number of people living in Ovambo. The Finnish missionaries treated 14600 inpatients and 160000 outpatients at their hospitals and clinics during $1960 .{ }^{45}$ In this year, about R90 000, out of a total sum of R1 260000 for the entire country, was allocated to healthcare in the whole northern sector, including areas outside Ovambo. ${ }^{46}$ The Finnish Missionary Society contributed R110000 the same year. ${ }^{47}$ The fact that there was no state hospital in the north is one conspicuous example of this biased allocation of resources.

\section{South African Social Engineering in the North}

Up to 1960 the medical services in South-West Africa followed a similar pattern to that in many other African colonies. Too few facilities, of low quality, providing inferior care, were available for the indigenous people, while whites were offered healthcare of higher quality in good facilities. Most hospitals and other facilities were provided close to the colonial centres, while the colonial powers relied on missionaries in other places. ${ }^{48}$

However, during the 1950s, the political situation changed dramatically in a number of important ways. In the ten years after 1957, the majority of colonies in Sub-Saharan Africa gained independence. ${ }^{49}$ In South-West Africa the nationalist movement started to organise itself with the foundation of the OPO, the Ovambo People's Organization, in 1959. Some years later, SWAPO ${ }^{50}$ was born which would eventually lead to South-West Africa becoming Namibia three decades later. In this context, the South-West African future was discussed and negotiated at an international level and the South African apartheid policies were subject to intensified international debate and criticism. A pivotal issue was a juridical one; whether South Africa had the right to remain in control of South-West Africa or not. ${ }^{51}$ An early legal intervention in 1960 was the Ethiopian and Liberian effort to raise a case against South Africa regarding South-West Africa in the International Court of the Hague. However, the case was dismissed for the reason that these countries were not eligible to raise the case in the first place. ${ }^{52}$

South Africa did not stay passive to the threat of losing control of the Namibian territory. Likewise, it had to deal with the international criticism of its neglect and abuse of the people in South-West Africa in order to strengthen its position in the UN negotiations and in the eyes of other international bodies and critics. A South African solution to these two problems was presented in the Report of the Commission of Enquiry into South-West Africa Affairs 1962-63 (the Odendaal Plan) which was a plan to formally implement the apartheid system in South-West Africa. ${ }^{53}$ This report suggested that a system of native reserves should be introduced, and implied that the territory would eventually be integrated as the

\footnotetext{
44 van Dyk, op. cit. (note 8), 87.

45 Odendaal Plan, op. cit. (note 16), 139.

46 Odendaal Plan, op. cit. (note 16), 141.

47 Odendaal Plan, op. cit. (note 16), 149.

48 Jennings, op. cit. (note 2); Charles M. Good, 'Pioneer Medical Missions in Colonial Africa', Social Science and Medicine, 32, 1 (1991), 1-10; Spencer H. Brown, 'A Tool of Empire: the British Medical Establishment in Lagos, 1861-1905', International Journal of African Historical Studies, 37, 2 (2004), 309-43.

49 Basil Davidson, Africa in Modern History (Harmondsworth: Penguin, 1978), 397.

50 SWAPO: South-West Africa People's Organization.

${ }^{51}$ Henry J. Richardson, 'Constitutive Questions in the Negotiations for Namibian Independence', The American Journal of International Law, 78, 1 (1984), 77-89.

52 Wallace and Kinahan, op. cit. (note 17), 261.

53 Odendaal Plan, op. cit. (note 16).
} 
fifth province. ${ }^{54}$ The plan was rejected by the UN. In 1966 the UN General Assembly stated that it was 'gravely concerned' about the situation in South-West Africa, and in resolution 2145 they declared that 'South Africa had failed to fulfil its obligations (... ) to ensure the moral and material well-being and security of the indigenous inhabitants'. ${ }^{55}$ Yet in defiance of the criticism put forward, South Africa implemented the homeland policy in South-West Africa from $1968 .^{56}$

The international criticisms South Africa faced concerned, among other things, health issues. There was a particular focus on health services in the Odendaal Plan. It was suggested that Ovambo should be a homeland of its own, Ovamboland, and would be improved in a number of ways. The report recommended a substantial increase in the capacity and quality of services in the north. Staffing, equipment, education, medical and material supplies and infrastructure were to be improved and enlarged ${ }^{57}$ The decision to construct a governmental hospital in the north had already been taken in $1961 .{ }^{58}$ The construction was indicated in the report as a desirable step in the development of the healthcare services. ${ }^{59}$ The South African government may have expected that the fact that it was a large capital project of strong symbolic value would impress the international audience. ${ }^{60}$ It was probably expected to be a physical representation of the omnipresent state and signify ostensibly a thorough South African engagement in the health of the northern people. ${ }^{61}$ Finnish missionaries welcomed the Odendaal Plan since they approved of the seclusion of Ovambo. ${ }^{62}$ They also expected that conditions that had been internationally criticised and held to be the responsibility of the South African administration of Ovambo would be rectified if the report's recommendations were realised. They also looked forward to the great infrastructural improvements that were envisaged in the plan. ${ }^{63}$

\section{The New Hospital in Oshakati}

In 1966, Oshakati hospital opened. The construction had been carried out in a notable way. The hospital buildings were made of prefabricated asbestos walls and iron sheet roofing produced in South Africa and transported an approximate distance of $2500 \mathrm{~km}$ by train to Tsumeb, 300km south of Oshakati located south of the Red Line. The lack of building materials in Ovambo was pointed out during the planning of the hospital, and sourcing the building materials from South Africa was a means of overcoming this deficiency. ${ }^{64}$

\footnotetext{
54 Odendaal Plan, op. cit. (note 16), 55.

55 UNGA Resolution 2145 (XXI), 'The Question of South-West Africa', UN General Assembly 21st session, $1966,2$.

56 Klaus Dierks, Chronology of Namibian History: From Pre-historic Time to Independent Namibia (Windhoek: Namibia Scientific Society, 1999), 130.

57 Odendaal Plan, op. cit. (note 16), 197-9.

58 'Suidwes-Afrika Administratsie Uitvoerenden Komite Besluit', Minutes, 8 September 1961. File no. 10/1/20/1, National Archives of Namibia, Windhoek.

59 Odendaal Plan, op. cit. (note 16), 197-9.

${ }^{60}$ Cpr. Barbara McPake, 'Hospital Policy in Sub-Saharan Africa and Post-colonial Development Impasse', Social History of Medicine, 22, 2 (2009), 341-60: 342.

61 Neil Andersson and Shula Marks, 'Work and Health in Namibia: Preliminary Notes', Journal of Southern African Studies, 13, 2 (1987), 274-92: 275.

62 Hellberg, op. cit. (note 22), 269.

63 Seppo Kjellberg, Finsk Mission och Apartheid i Namibia. En Översikt av Finska Missionssällskapets Inställning till Rassegregationen i Sydvästafrika [An Overview of the Finnish Missionary Society's Attitude to Race Segregation in South-West Africa] (Åbo: Åbo Akademi, 1972), 35.

${ }^{64}$ Odendaal Plan, op. cit. (note 16), 177.
} 
The large and heavy building components were reloaded from the train to lorries and the transportation continued to Oshakati where the walls were erected. This was done with great difficulty, according to the head nurse of the South African local administration. 'Problems galore!' she exclaims in her article. ${ }^{65}$ The extremely awkward production and transport of the building elements suggests that the South African authorities had little confidence in the resources of northern South-West Africa. The German habit of using local building materials and hybrid architectural forms that blended with local architecture was not copied by South Africans. ${ }^{66}$ The Germans had produced both cement bricks and adobe bricks; construction materials based on local matters the South Africans obviously did not adopt in the northern areas. ${ }^{67}$ Neither were building techniques adapted to local resources even though people from the area were recruited as labourers. Even concrete ballast came from Tsumeb. ${ }^{68}$

\section{The Design of the Hospital}

When the hospital was inaugurated it was severely undersized for its mission of serving the approximately 230000 people living in the area. ${ }^{69}$ The hospital had 444 beds. Beds for black patients were divided among three general wards for adults, one ward for children, one maternity ward and four tuberculosis wards of which one was for children. Each inpatient ward contained about 40 beds. There were also a surgical theatre, an outpatient department and a dispensary. There were offices for administration and buildings for the nursing school (Figure 6). ${ }^{70}$

The buildings were robust and rough, both the exteriors as well as the interiors. A simple corridor ran through the greyish inpatient wards. Meals were served in the dining-hall on sturdy tables to patients who sat on benches made of wood (Figure 7). ${ }^{71}$ Covered walkways connected the wards and protected patients and staff from the harsh climate, sun and sand (Figure 8). ${ }^{72}$

The apartheid ideology was visible in the design of the hospital. White patients were offered a substantially higher standard than blacks, with a special inpatient ward with four private en-suite rooms with patios and baths, and a delivery ward (Figure 9). ${ }^{73}$

The initial planning also revealed other biased allocations of resources based on race. The water supply had to be rationed. This was done according to the apartheid logic. Whites' consumption of water for cooking and drinking was estimated to be twice as high as that of the blacks. A black patient was allocated 17.5 gallons of water daily, whereas a

\footnotetext{
65 Annchen Bremer, 'The State Hospital, Oshakati, Ovamboland', SA Nursing Journal, 33, 10 (1966), 13-14.

66 Ithoam I Osyaimwese, 'Colonialism at the Center: German Colonial Architecture and the Design Reform Movement, 1828-1914' (Unpublished PhD: University of Michigan, 2008), 117-20.

67 Walter Peters, 'Wilhelminian Historicism and Objectivity. The Reception of German Architecture during the Period 1882-1914 in the Former German South-West Africa (Namibia)', (1983), http://www.namibweb.com/ archit.htm (accessed 21 October 2012).

${ }^{68}$ Bremer, op. cit. (note 65), 14.

69 Population figure from the Odendaal Plan, op. cit. (note 16), 41.

70 Bremer, op. cit. (note 65), 13-14; Ministry of Works, Transport and Communication Drawing Archive, Windhoek. Drawing 1383/2. 'Okatana hospital, Ovamboland, complete building layout showing foundations', 7 July 1962.

71 Design and furnishing according to the author's own observation.

72 Bremer, op. cit. (note 65), 13.

73 Bremer, op. cit. (note 65), 13; Drawing: 'Okatana hospital, Ovamboland, Plan of European ward block', Date and Drawing no. missing, Ministry of Works, Transport and Communication Drawing Archive, Windhoek.
} 


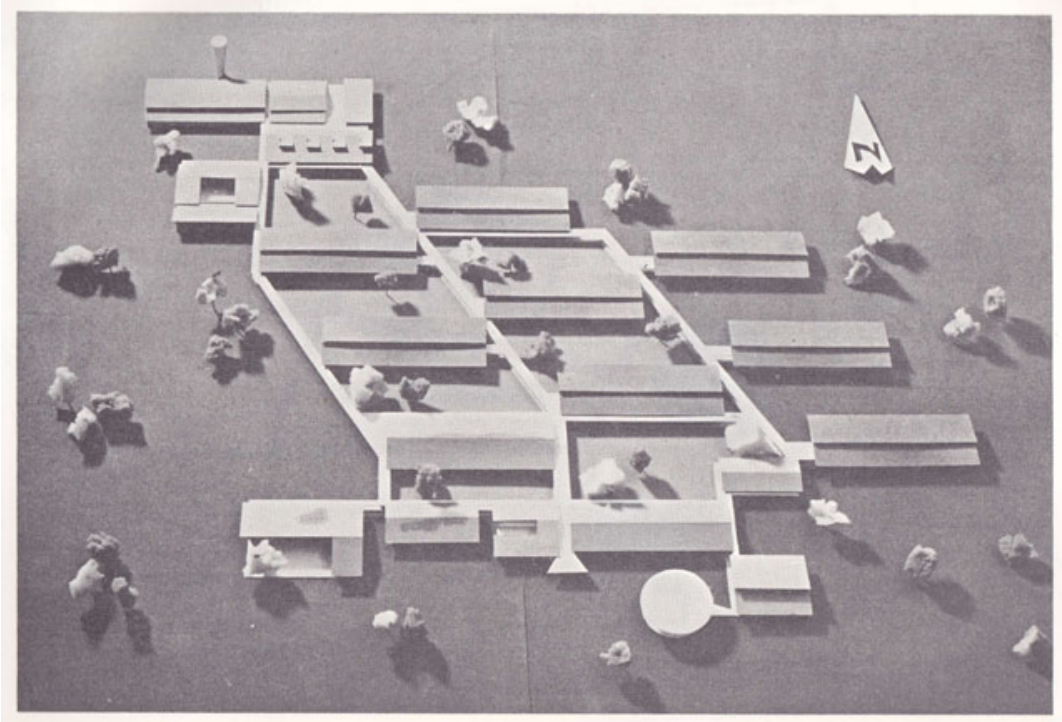

Figure 6: Oshakati hospital as envisaged during the planning. This master plan is to a large extent the one that was completed. Source: Report of the Commission of Enquiry into South-West Africa Affairs 1962-3, 175.

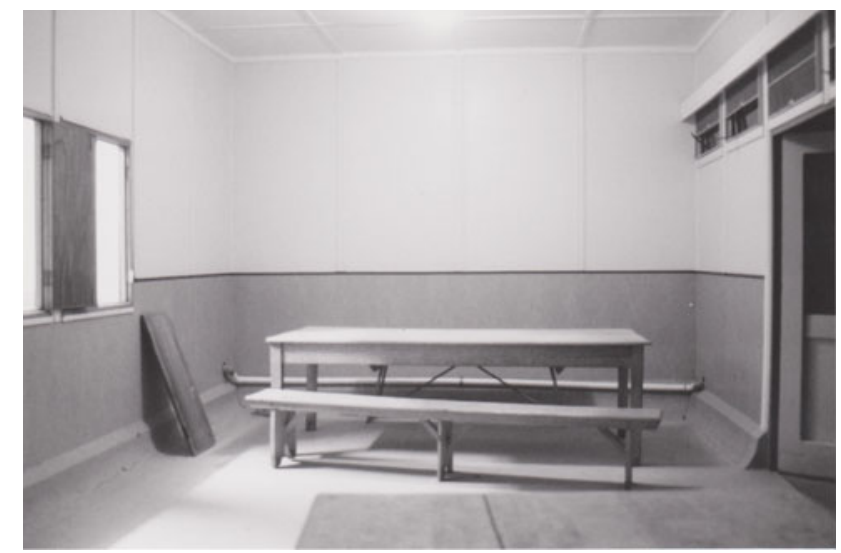

Figure 7: Dining-hall with sturdy furniture in an inpatient ward in Oshakati hospital. Photo: The author, 2000.

white family of four were allocated 150 gallons in total. Whites were expected to take daily baths while blacks were not expected to take any baths at all, just occasional showers. ${ }^{74}$

Staff accommodation was subject to similar considerations. Accommodation needs for various staff categories, 'European' as well as 'non-European', had already been estimated in $1962,{ }^{75}$ but the estimation was too low. When the hospital was finished, more

74 'Water supply Okatana, Minutes from meeting about water allocation', 29 June 1962. File no. 10/1/20/1, National Archives of Namibia, Windhoek.

75 Letter to the Director of Works from the Director of Health Services. Accommodation: staff state nonEuropean hospital, Okatana - Your C.O. 31 dated 25 April 1961, Refers 17 August 1962. File no. 10/1/20/1, National Archives of Namibia, Windhoek. 


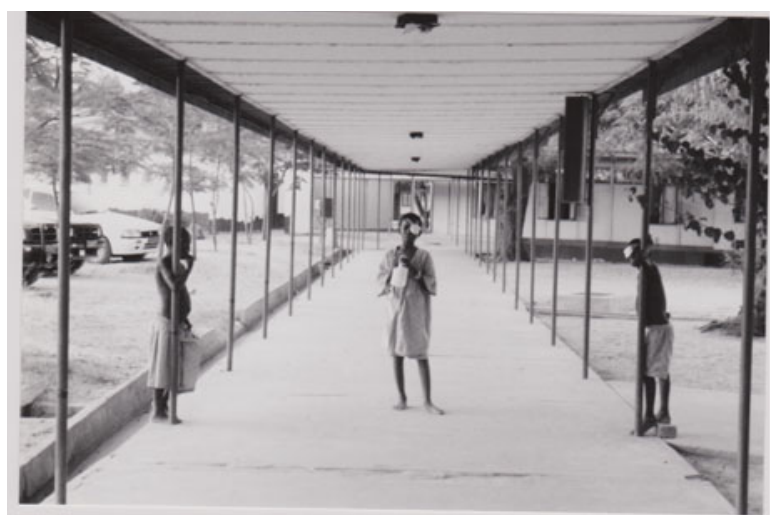

Figure 8: The covered walkways connecting the wards in Oshakati hospital. Young patients from the ophthalmology clinic. Photo: The author, 2000.

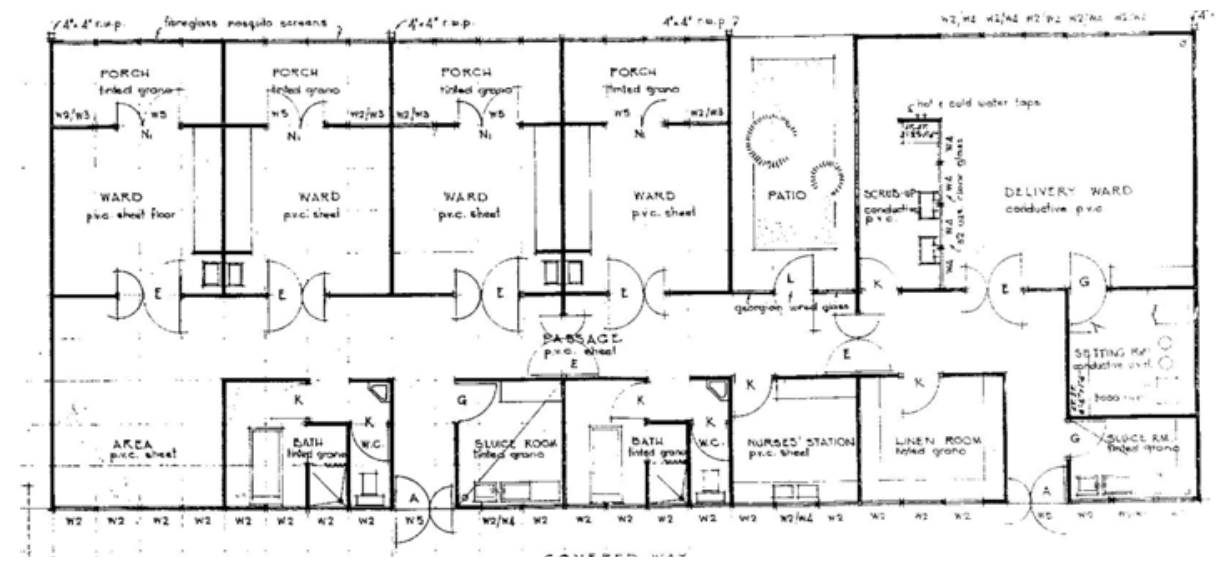

Figure 9: European ward block in Oshakati hospital. Drawing 'Okatana hospital, Ovamboland, Plan of European ward block'. Source: Drawing Archive in Ministry of Works, Transport and Communication.

accommodation had to be added. ${ }^{76}$ The quality of accommodation for the various types of staff reflected both their respective place in the hospital staff hierarchies, as well as the colour of their skin. White doctors and non-medical staff were provided with a family house or flat. Two types of accommodation for nurses were provided. 'European sisters' were accommodated in double-room flats with a kitchen in the patio and shared entrance and bathrooms. ${ }^{77}$ 'Non-European' nurses, auxiliary nursing staff and nursing students lived in so-called single quarters. ${ }^{78}$ White staff were also provided with a tennis court and a swimming bath. ${ }^{79}$

\footnotetext{
76 Bremer, op. cit. (note 65), 14.

${ }^{77}$ From the author's own observation.

78 Letter, op. cit. (note 75); Drawing 86/48/01T, 'Oshakati Hospital Uitbreidnings \& veranderings aan best wasseryblok, terrain plan', Oct, 1986. Ministry of Works, Transport and Communication Drawing Archive, Windhoek.

${ }^{79}$ Letter, op. cit. (note 75).
} 


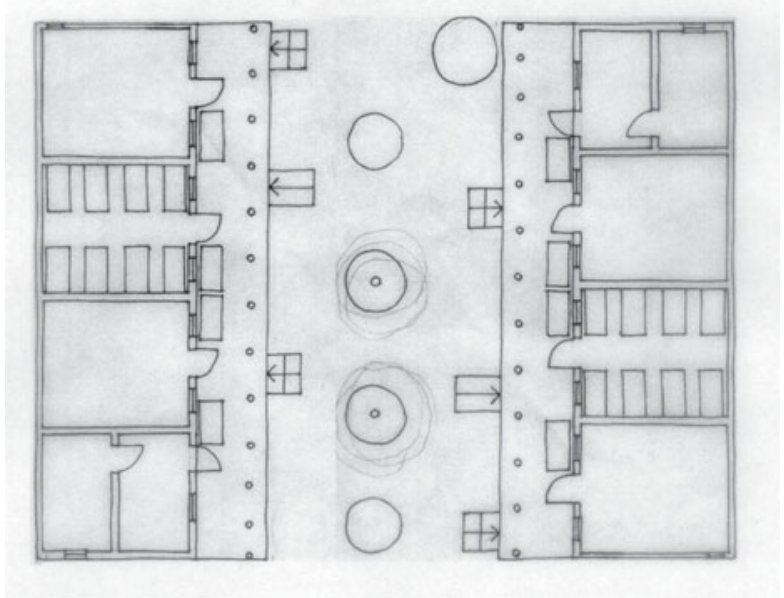

Figure 10: Sketch of the two clay inpatient wards in Onandjokwe hospital. Source: The author.

The separated accommodation had a practical rationale. Black and white staff members were not allowed to socialise outside working hours. This was, however, not acceptable to all white staff. The Finnish nurses who had started working in 1966 gave their notice quite quickly when they realised that they were not allowed to speak to black colleagues or patients during their time off. They also refused to register as white nurses, as they were requested to by the local health administration. ${ }^{80}$

\section{Ideological and Discursive Dimensions of Healthcare}

The main building of Onandjokwe hospital from 1911 and two early inpatient wards were still in use in 1997. The latter two were juxtaposed buildings with sturdy clay walls, serving as inpatient facilities with three wards for four patients each. Each building also contained two small rooms for the nurse's station and a store located in the corner (Figure 10). The doors from the wards opened onto the veranda where patients who had chosen to stay outside were shaded by the overhanging roof, which was still supported by tree trunks (Figures 11 and 12). These two buildings were hybrids, born out of a crossfertilisation of a European modern inpatient ward model and Ondonga architecture and building techniques. They were constructed by people who seemed to have other attitudes than those who constructed the Oshakati hospital. While the missionaries relied on local resources, the South Africans did not, except for manpower. Fifty years may separate the inceptions of the two hospitals but a decisive difference in attitudes is discernible. Where South Africans saw problems, the missionaries saw possibilities.

Missionaries have been alleged to be narrow-minded, opposing what they regarded as 'sinful' indigenous cultural practices, and cooperating with colonial powers. Also Finnish missionaries were a product of their time and their relationship with locals was coloured by racist mind-sets, contempt and open resistance to certain central elements in the Ovambo culture, such as the female initiation rite. ${ }^{81}$ There were civilising ambitions

${ }^{80}$ Kjellberg, op. cit. (note 63), 34.

81 Miettinen, op. cit. (note 34), 128. The Ovambo female initiation was called Ohango in Oshindonga and Efundula in Oshikwanyama. Idem, 50. 


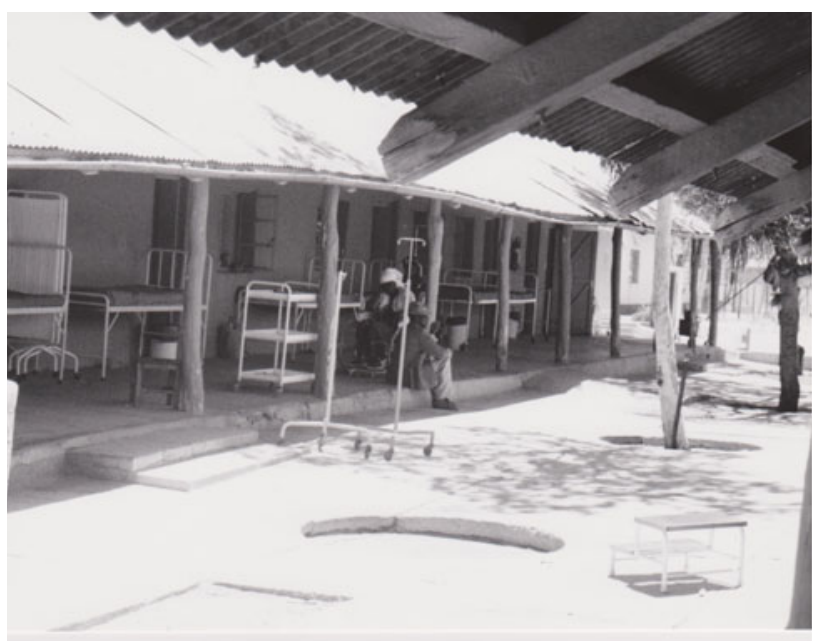

Figure 11: The yard between the juxtaposed inpatient ward buildings in Onandjokwe. Photo: The author, 1997.

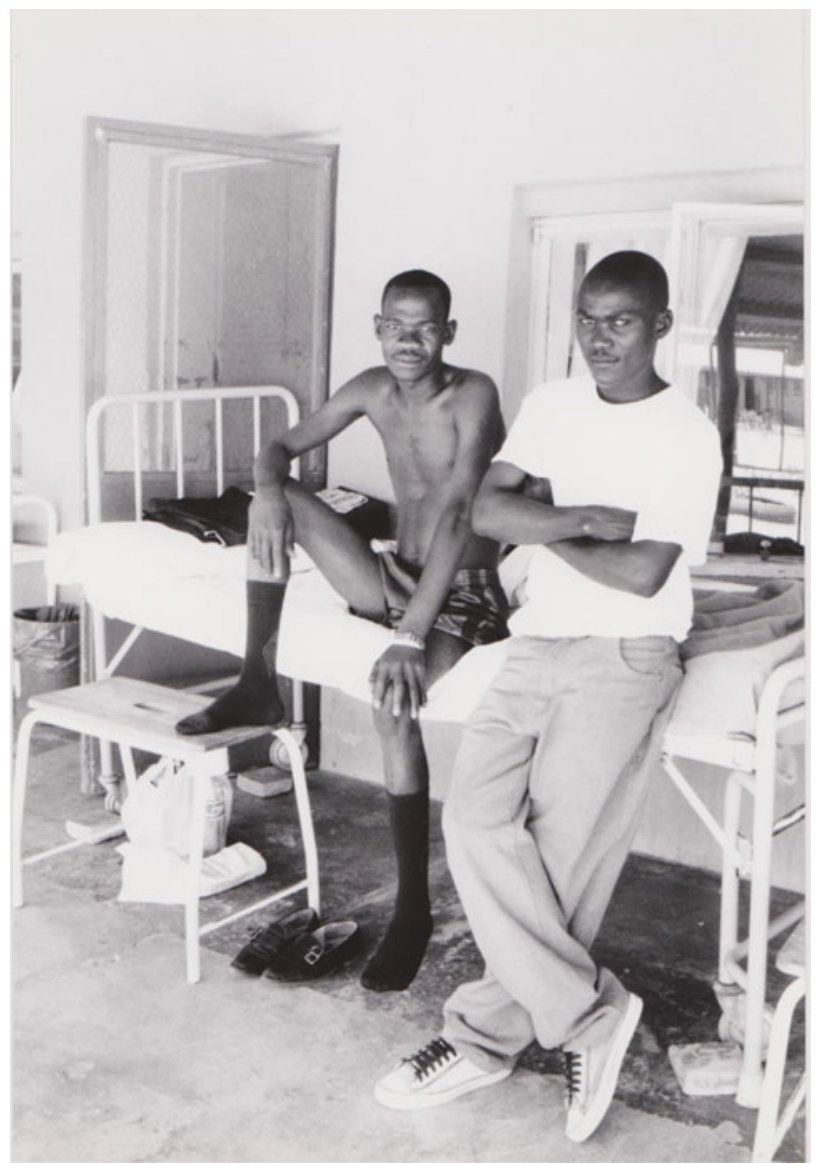

Figure 12: A friend visiting a patient on the veranda in the old clay ward in Onandjokwe hospital. Photo: The author, 1997. 
embedded in the education, healthcare and religious teaching the missionaries offered to the local people in the north. ${ }^{82}$ Medical care was a deliberately used means of attracting people to the missionary stations. ${ }^{83}$ Hospitals are evident parts of highly visible curative care that could well have supported the conversion of local people. ${ }^{84}$ The missionaries' views of South Africans and apartheid were ambiguous, balanced between criticism and acceptance. Individual missionaries did not seem to agree, and the topic was subject to internal debate. Violence and abuse were not acceptable to the missionaries. Some were against apartheid, but in general they were not against separation of whites and blacks. ${ }^{85}$ The reason for keeping a low profile regarding the South Africans was related to the South African funding of Finnish health services and the control of the missionaries' presence in the area by the issuing of residence permits. In fact, South Africa refused to extend some of the missionaries' visas during the 1960s. ${ }^{86}$ Some missionaries argued that excessively strong criticism of apartheid would jeopardise their presence and consequently the Christianisation of the Ovambo people. However, no one was expelled. ${ }^{87}$ Their concerns about the visa issue were not entirely unfounded. What they feared actually happened later in Zimbabwe where missionary health workers were forced to leave the country during the liberation war because of accusations that they had given aid to freedom fighters. ${ }^{88}$ The South African government also seemed to have an ambivalent attitude towards the Finns since it depended on the Finnish healthcare contribution in the north, yet it had the opinion that the Finnish missionaries were meddling in Ovambo issues. ${ }^{89}$

It is possible that the missionaries did not realise that the South Africans' dependence on them as major healthcare providers in the north had consequences for the government's administration. This dependence seemed to increase with intensified international criticism against apartheid since no missionary was actually asked to leave the country. The absence of missionary criticism of the homeland system seems naïve with the information they had available about South African abuse of local people. On the other hand, criticism from missionaries may not have made a great difference in practice, although it would have presented a standpoint of symbolic significance, especially for their black colleagues. There was severe tension between OPO/SWAPO and the missionaries during the late 1950s and early 1960s. The Finnish missionaries were accused of being against the liberation movement. ${ }^{90}$ The missionaries' ambivalence may have prevented them from foreseeing what would happen in the health service area. They did not seem to recognise that a total disaster was approaching. Taking into account the small size of each homeland and the limited funds available, the provisions that were recommended in the Odendaal report were impossible to deliver. Resources continued to be disproportionally distributed between the different population groups. In 1981 the per capita expenditure for white people's healthcare in South-West Africa was R243, while the sum spent in Ovambo

${ }^{82}$ Miettinen, op. cit. (note 34), 87-100; Hellberg, op. cit. (note 22), 208-209.

${ }^{83}$ Miettinen, op. cit. (note 34), 93-96.

${ }^{84}$ McPake, op. cit. (note 60), 342.

85 Kjellberg, op. cit. (note 63).

${ }^{86}$ Iina Soiri and Pekka Peltola, Finland and the National Liberation in Southern Africa (Uppsala: Nordic Africa Institute, 1999), 59-60.

${ }^{87}$ Kjellberg, op. cit. (note 63), 50-2.

${ }^{88}$ Gerald Bloom, 'Two Models of Change in the Health Services in Zimbabwe', International Journal of Health Services, 15, 3 (1985), 451-68: 455.

${ }^{89}$ There was for example a long conflict with the Ovambo 'Native Commissioner' Carl Hahn. See, for instance, Hellberg, op. cit. (note 22), 211-13. For further information see below.

${ }^{90}$ Miettinen, op. cit. (note 34), 172-3. 
was R25. ${ }^{91}$ The homeland policy led to extreme situations in that it fragmented health services. ${ }^{92}$ They varied in quality and accessibility in different areas. While it was impossible to get access to care in certain areas, there were excess services in other areas due to the double provision of facilities for whites and blacks. Primary care was the focus in a few homelands, while hospital-based curative care was the only option in others. ${ }^{93}$ However, curative services provided in hospitals could do little to impact on the general health situation, which needed public health interventions rather than medical treatment of individual patients. ${ }^{94}$ In Ovambo the curative hospital-based healthcare continued to dominate and would grow even stronger in the years to come because of the political developments that waited around the corner. This was a period when hospital-based care was called into question and it was argued that making general public health interventions was the means to come to terms with Africans' health problems. ${ }^{95}$ While there was a marked decline in numbers of medical staff in missions in other countries at the dawn of independence, ${ }^{96}$ the Finnish missionaries were able to continue both their medical and evangelising endeavours in South-West Africa.

Even though they were careful in their attitudes towards South Africans, the Finnish missionaries seemed to have had the advantage of not being associated with any colonial power, whereas all other missionary societies active at the same time did have such associations to some extent. ${ }^{97}$ Finnish missionaries worked in close cooperation with local leaders, especially with the Ondonga kings. Oniipa missionary station was located on land that the Ondonga king had provided. ${ }^{98}$ They started early on to educate local religious leaders, which would have a decisive influence on the future relations with the liberation movement. ${ }^{99}$

\section{Healthcare in the Context of War}

1966 was a year when many incidents occurred that had a great bearing on the future political situation in South-West Africa, particularly in the northern part. That year the first hostilities between PLAN ${ }^{100}$ guerrilla soldiers and South African police took place in Ongulumbashe, not far from the hospital. PLAN was the military wing of SWAPO. The same year, the UN General Assembly proclaimed that the South African rule by mandate of South-West Africa was terminated. ${ }^{101}$ However, the South African government ignored this resolution. ${ }^{102}$ Instead, South Africa reacted to the heightened activities of PLAN with a heavy armed response. From 1979 to $1988,{ }^{103}$ SADF was permanently present in

\footnotetext{
${ }^{91}$ International Defense and Aid Fund, op. cit. (note 6), 20.

92 van Dyk, op. cit. (note 8), 85.

93 Interview with MoHSS officer.

94 Shula Marks and Neil Andersson, 'Issues in the political economy of health in southern Africa', Journal of Southern African Studies, 13, 2 (1987), 177-86.

95 Charles M. Good, The Steamer Parish. The Rise and Fall of Missionary Medicine on an African Frontier (Chicago, IL: Chicago University Press, 2004), 427.

96 Ibid., 419.

${ }^{97}$ Hellberg, op. cit. (note 22), 193-215.

98 Wallace and Kinahan, op. cit. (note 17), 93.

99 Wallace and Kinahan, op. cit. (note 17), 213.

100 PLAN is the People's Liberation Army of Namibia.

101 UNGA Resolution 2145 (XXI), op. cit. (note 5), 2.

102 Van Dyk, op. cit. (note 8), 83.

103 Jannie Geldenhuys, At the Front. A General's Account of South Africa's Border War (Johannesburg: Jonathan Ball Publishers, 1990).
} 
northern South-West Africa, which turned the north into a war zone. ${ }^{104}$ The South African focus was on Ovambo where military bases were established in a considerable number of places. ${ }^{105}$ However, the conflict was not 'of a conventional-warfare type (...) this was a counter-insurgency campaign which consisted of a multitude of small-scale encounters in a "combat" zone'. ${ }^{106}$ The 'combat zone' included places where people lived; hence the widely dispersed nature of the hostilities had a profound and disastrous effect on civilians and their everyday lives. People were subject to violent encounters with Koevoet, the South African special military police force, who patrolled the area in heavy vehicles in search of PLAN soldiers. ${ }^{107}$ SWAPO members were detained and thousands of people fled the country, into neighbouring countries or overseas. ${ }^{108}$

\section{Militarisation of Civil Medicine}

The intensification of the conflict completely changed the conditions for the hospital in Oshakati. The immediate surroundings of the hospital were fortified and fenced when a major South African base was established in the immediate vicinity. The entrance to the base was opposite the entrance to the Oshakati hospital (Figure 13). From 1982 and onwards Oshakati 'was the most fortified town in the war-torn Ovambo (...) surrounded by watch towers, security fences and bullet-proof walls' ${ }^{109}$ The base included the headquarters for Sector 10 (Ovamboland), the 52 Battalion and Koevoet. ${ }^{110}$ It was organised with military infrastructure and personnel, to cater for soldiers when they were both on and off duty. ${ }^{111}$

A military hospital inside the base was staffed with military medical personnel at all levels, medical doctors as well as operational medical orderlies (ops medics). This was the main casualty evacuation hospital. ${ }^{112}$ Oshakati hospital became involved in the SADF machinery. It was staffed by the military and it was used (up to 1983) by the army when Xray examinations were needed. ${ }^{113}$ In Oshakati hospital only five out of seventeen doctors were civilians. ${ }^{114}$ From 1983 onwards the director of the medical services in Ovambo was

104 Wallace, op. cit. (note 6), 293-4.

105 Geldenhuys, op. cit. (note 103), 82; Helmoed-Romer Heitman, Modern African Wars (3) South-West Africa (Oxford: Osprey Publishing, 1991), 14.

106 Geldenhuys, op. cit. (note 103), 68.

107 Wallace and Kinnahan, op. cit. (note 10), 295-6; See internet pages for conscripts' personal accounts: http:// www.youtube.com/watch? $\mathrm{v}=\mathrm{uV}$ pNQ3TMWDQ\&feature=related, http://www.youtube.com/watch?v=VHipfae4 qrM\&feature=player_embedded, http://sadf.sentinelprojects.com/index.html and http://bethlehemssappers.blogs pot.com. A warning should be expressed about these pages. Their content can be perceived as disturbing. They represent a number of internet sites displaying private photos, films and stories about the Border war. They are characterised by a military romanticised approach to the topic. They glorify violence and put forward admiration for weaponry and armoured vehicles combined with a boyish or male chauvinist spirit. Regrets that the war is over are expressed in these pages.

108 Dierks, op. cit. (note 56), 143.

109 Hangula. op. cit. (note 1), 24-5.

${ }^{110}$ Heitman, op. cit. (note 105), 14, 21; Interview with former operational medical orderly on duty in Oshakati in early 1980s (ops medic).

${ }^{111}$ Barry Fowler, Grensvegter? South African Military Psychologist, http://sadf.sentinelprojects.com/gv/gvtoc.h tml. Retrieved 5 November 2011.

112 Truth and Reconciliation Commission (TRC), Human rights violations: Health sector hearings (Submission by the South African Medical Services), 17 June 1997, http://www.justice.gov.za/trc/special/health/health01.ht m, retrieved 3 April 2011 (hereafter TRC 1997). Later the evacuation hospital was moved to the Ondangwa base. Ibid.

113 Interview with ops medic.

114 The military staffing of Oshakati hospital seemed to have stopped during the latter part of the conflict. Fowler, op. cit. (note 111). 


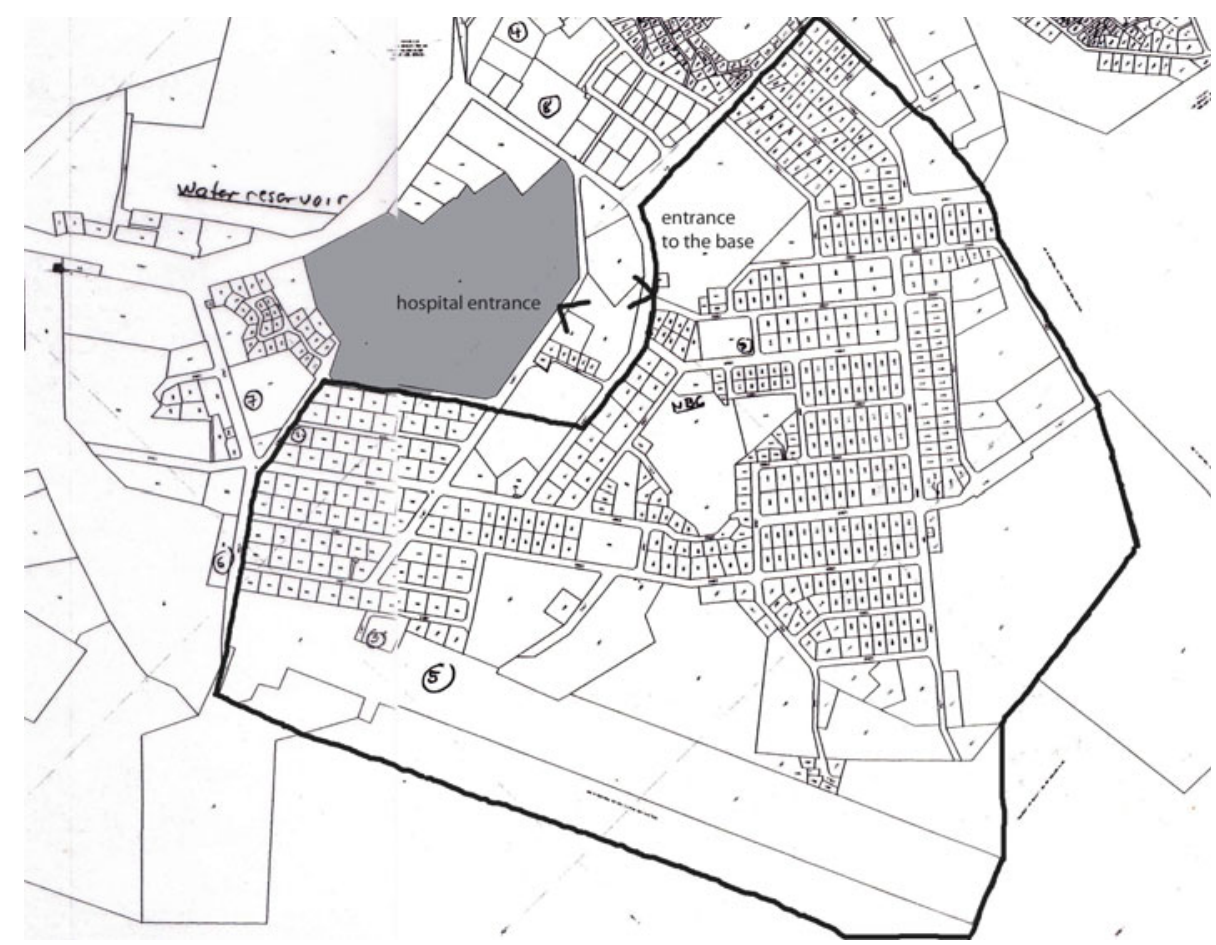

Figure 13: Map of Oshakati in the year 2000. The black line indicates the approximate extension of the base. The greyish area indicates the Oshakati hospital grounds. The arrows indicate the Oshakati hospital entrance and the base entrance that were just opposite each other. Reconstructed from the Structure Plan for Oshakati, General Layout Plan, Ministry of Regional and Local Government and Housing, Oshakati Town Council. Drawing no: 5370-G-01.

a SADF colonel. ${ }^{115}$ This was part of the SADF medical department, the South African Medical Services, headed by a Surgeon General. ${ }^{116}$ Boundaries between civil healthcare and warfare evidently became blurred. The daily tasks in the hospitals changed due to the hostilities. Oshakati hospital dealt with civilian casualties. The hospital received patients who had lost arms and legs, often by landmine explosions. Some patients were people who had been beaten or shot by the South African military after being mistaken for PLAN guerrilla soldiers. ${ }^{117}$

However, the war generated patients not only by military operations, but also by the most shameful of war activities, torture. A testimony in the Truth \& Reconciliation hearings revealed that in the Koevoet detention cells in the Oshakati base a suspected PLAN soldier had had boiling water poured over his chest and genitals during interrogation. It had been discovered that he was a civilian and had no SWAPO connections at all, so the incident had to be concealed. The testifying ops medic was told to attend to this patient without telling anyone. 'I didn't know what to do, I was not qualified (... I I called in the help of a doctor from Oshakati Hospital (...) and told him not to tell anybody

115 International Defense and Aid Fund, op. cit. (note 6), 29-30; interview with former staff member in Onandjokwe hospital.

116 TRC 1997, op. cit. (note 112).

${ }^{117}$ International Defense and Aid Fund, op. cit. (note 6), 28. 
but to please deal with the patient'. ${ }^{118}$ The Oshakati hospital, although basically a civilian hospital, was a resource in this ops medic's world. However, the Koevoet's murky activities defined the limits of the military/civilian cooperation. The testimony later revealed that the man was never brought to Oshakati hospital because an explanation for his condition would then have been necessary. ${ }^{119}$

\section{Three New Governmental Hospitals}

The war made healthcare services available that had not existed before. As a matter of fact, huge resources were allocated to healthcare in the area; however, much less than the money that was spent on the war. ${ }^{120}$ The SADF tried to influence the local inhabitants in the war zone by employing the 'win the hearts and minds' strategy. ${ }^{121}$ The South African version of this strategy had the explicit aim of improving the relationship with local people by offering healthcare to them. The staffing of the Oshakati hospital with military personnel to improve the quality of medical care and access to it was one part of that strategy. ${ }^{122}$ Another was that military medical personnel on duty were instructed to provide medical assistance to civilians in the area called Community Operations (COMOPS). ${ }^{123}$ A third component of the strategy was the supply of medical facilities.

During the 1980s, Oshakati hospital was complemented by another three new governmental hospitals in Ovambo: Ombalantu (Nakanyale), Tsandi and Okahao hospitals. All three hospitals were constructed within a small geographical area at very short distances from each other. Tsandi and Okahao hospitals were about $25 \mathrm{~km}$ apart and the hospital in Ombalantu was about 40km away from the others. This sudden generous provision in a limited area while the rest of Ovambo was still neglected was linked to the winning the hearts and mind campaign. The South Africa administration cooperated with some of the local headmen and provided them with 'seductive donations' ${ }^{124}$ The hospitals were located in the respective jurisdiction areas of three Ovambo groups, Ombalantu, Uukwaluudhi and Ongandjera, with the aim of keeping local headmen satisfied and cooperative (Figure 14). ${ }^{125}$ The three hospitals were akin to the hospital in Oshakati in type and in building techniques. All were a model type of hospital. They had similar layouts (the Tsandi and Ombalantu hospitals were identical) in which inpatient wards and other buildings were connected with a system of covered walkways. Their sizes were comparable. ${ }^{126}$ Although very close to each other, they did not represent a parallel facility provision for whites only. These hospitals were for civilian use, and were intended for black patients. As a matter of fact, the nearby base and the hospital were explicitly kept apart. Despite the fact that medical staff were supposed to support local people with healthcare according to the COMOPS scheme, in this case the military doctor on duty

\footnotetext{
118 Truth and Reconciliation Commission (TRC), Amnesty Hearing Transcripts: Various cross-border activities, 31 July 2000, http://www.justice.gov.za/trc/amntrans/2000/200731pt.htm, retrieved 3 April 2011 (hereafter TRC 2000).

119 Ibid.

120 Andersson and Marks, op. cit. (note 61), 274.

121 Anthony B. Zwi, 'The Political Abuse of Medicine and the Challenge of Opposing it', Social Science and Medicine, 25, 6 (1987), 649-57.

122 International Defense and Aid Fund, op. cit. (note 6), 29.

123 TRC 2000, op. cit. (note 118).

${ }^{124}$ Interview with MoHSS officer; Hangula, op. cit. (note 1), 17.

125 Interview with MoHSS officer.

126 From the author's own observation.
} 

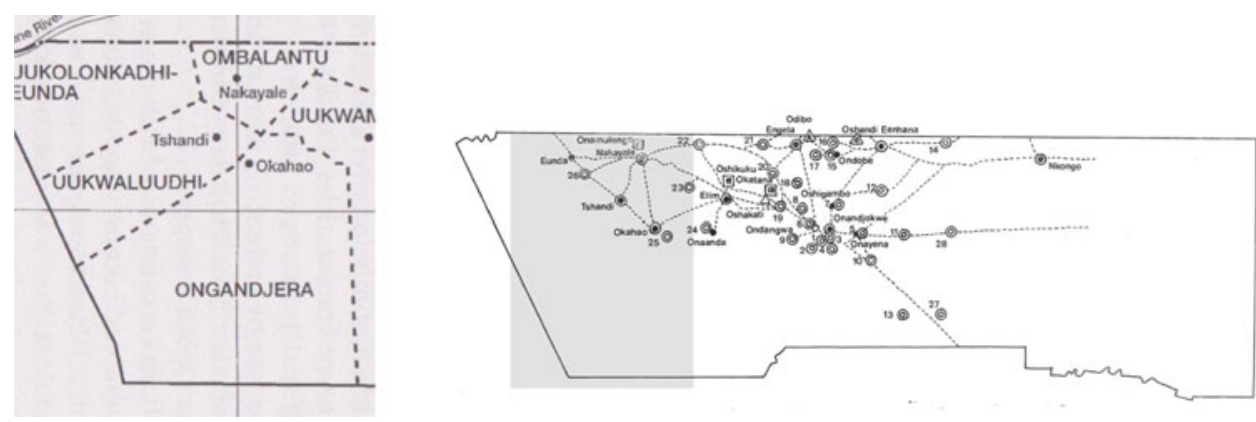

Figure 14: Three new hospitals constructed in Tsandi, Okahao and Nakayale corresponding to the ethnic groups Uukwaluudhi, Ongandjera and Ombalantu, respectively. (The grey area is marked on the Finnish Missionary Society map of health facilities in Ovambo, Figure 5). Source: Notkola and Siiskonen, (note 18), 33.

in the base was not allowed to support the local hospital, even though it did not have a doctor and was only $1 \mathrm{~km}$ away. This was due to an attack on the base by suspected local PLAN soldiers that had taken place. ${ }^{127}$ Military considerations weighed heavier than local people's healthcare needs.

There is another reason for the construction of the three hospitals that is linked to the missionary facilities and the PLAN soldiers assumed use of them. The hospitals may have been constructed with the aim of circumscribing the influence of the missionary facilities or even getting rid of them. The new hospitals were constructed in places where there were missionary clinics or small hospitals in operation (Figure 14). These clinics were closed down as a consequence of the construction of the new hospitals. Finnish missionaries were neither informed about the construction of the new hospitals nor asked to run them. ${ }^{128}$ Without missionary hospitals it was anticipated that the guerrilla soldiers, who were assumed to seek treatment there, would then find themselves deprived of medical care or be forced to go to a government hospital. ${ }^{129}$

\section{A 'Terrorist' Hospital}

The latter reason for the construction of the new hospitals mentioned above points to the links the South Africans saw between the missionaries and the liberation movement. The missionary work had led to the start of the Evangelical Lutheran Ovambo-Kavango Church (ELOK) in 1954. In 1963 the first bishop was elected, Leonard Auala, an Ovambo man. Under his leadership the church took a stand against the South African rule and openly criticised the conditions in Namibia. ${ }^{130}$ ELOK took a central position among those supporting the liberation movement. ${ }^{131}$ From the early 1970 s onwards, the Finnish missionary society became unanimously and openly supportive of SWAPO. ${ }^{132}$

Onandjokwe hospital, just like Oshakati hospital, received patients who had been involved in war-related incidents. According to staff members working there at the time,

\footnotetext{
127 Sentinel Projects: Doctor, http://sadf.sentinelprojects.com/propat/5cw.html, accessed 6 July 2010.

128 Interview with former Onandjokwe hospital staff member.

129 Interview with MOHSS officer.

${ }^{130}$ Kaire Mbuende, 'Church and Class Struggle in Namibia', in Peter Katjaviv, Per Frostin and Kaire Mbuende (eds), Church and Liberation in Namibia (London: Pluto Press, 1989), $27-47$.

131 Ibid., 45.

${ }^{132}$ Kjellberg, op. cit. (note 63), 61; Soiri and Peltola, op. cit. (note 86), 64.
} 
many patients who were wounded by landmine explosions, shooting or other casualties arrived in the hospital. South Africans must have drawn the conclusion that PLAN soldiers, if they could avoid it, most probably would not go to Oshakati hospital due to its proximity to the base. That seems a highly likely strategic analysis. Although most of the patients were civilians, it sometimes happened at night that the Onandjokwe hospital was approached in the dark by wounded PLAN soldiers who asked to see an Ovambo doctor who worked there. They left before dawn. The Onandjokwe hospital was labelled 'a terrorist hospital' by the South Africans. Occasionally the hospital was raided by SADF soldiers who entered the wards and removed bandages from patients to look for concealed weapons. They never found anything, according to interviewed staff. ${ }^{133}$

To target health facilities with violence was included in the South African strategic arsenal. The South Africans deliberately destroyed hospitals and clinics in neighbouring Mozambique, with severe consequences for local people. ${ }^{134}$ Open protests against South Africa brought the violence closer to Onandjokwe hospital. Shortly after Bishop Auala paid a visit to the South African Prime Minister Vorster in 1973, in which he conveyed complaints about the conditions in Namibia, the ELOK's office and printing facility in Oniipa, just outside the Onandjokwe hospital compound, was destroyed in a bomb blast (Figure 15). The printing office produced the only critical newspaper in the area. ${ }^{135}$ The police investigation, undertaken by the South African police, never found the perpetrators. ${ }^{136}$ This was the first time the offices were destroyed. Another blast targeted the same offices seven years later. ${ }^{137}$ A third bomb was discovered and disarmed in the hospital in 1984. This time the missionary society openly accused the SADF military of having placed the bomb whilst conducting an inspection of the hospital. ${ }^{138}$

There were other, more subtle signs, suggesting that the South Africans were punishing the missionaries for their alleged cooperation with SWAPO. New staff were discouraged from working at the Onandjokwe hospital. In 1982, hundreds of patients were treated every day by only two doctors, since South African visa policies had reduced the number of Finnish staff. ${ }^{139}$ Although the war entailed a huge increase in resources to the medical sector in Ovambo, the allocation of these resources was uneven. Onandjokwe hospital asked repeatedly for assistance in staffing, but the SADF military in charge of the local health authority refused to assist the hospital with more staff. For a year there was only one doctor on duty, who was burdened with an extreme work load. ${ }^{140}$

Onandjokwe hospital became linked to the war and to the independence movement in the eyes of the South Africans, which made the hospital, its staff and patients, vulnerable to threats, aggression and fear. The hospital became intertwined in a highly tangible way with political aspirations that a hospital is not normally associated with. Hirst argues that war 'often links together structures and places that seem to us to belong to very different

\footnotetext{
133 Interview with former Onandjokwe hospital staff member.

134 Julie Cliff and Razak Noormahomed, 'Health as target: South Africa's destabilization of Mozambique', Social Science and Medicine, 27, 7 (1988): 717-18.

135 Ibid., 63.

136 Dierks, op. cit. (note 56), 141.

137 Oniipa-Tryckeriet efter Attentatet 19.11.1980 [The Oniipa Printing Office after the Attack 19.11.1980] Missionsnytt, [Missionary News], 1980.

138 'Bomb Found at Namibia Hospital, South Africans Suspected', Namibia Newsletter, October 1984.

${ }^{139}$ International Defense and Aid Fund, op cit. (note 6), 29.

${ }^{140}$ Interview with former Onandjokwe hospital staff member.
} 


\section{missionsnytt}

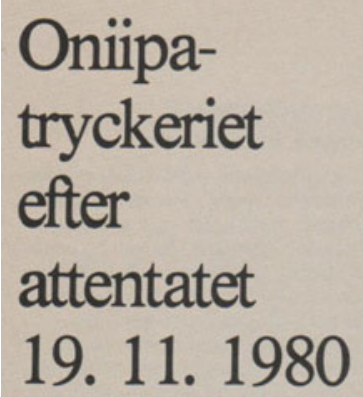

Foto: Tapani Ruokanen/ Suomen Kuvalehti

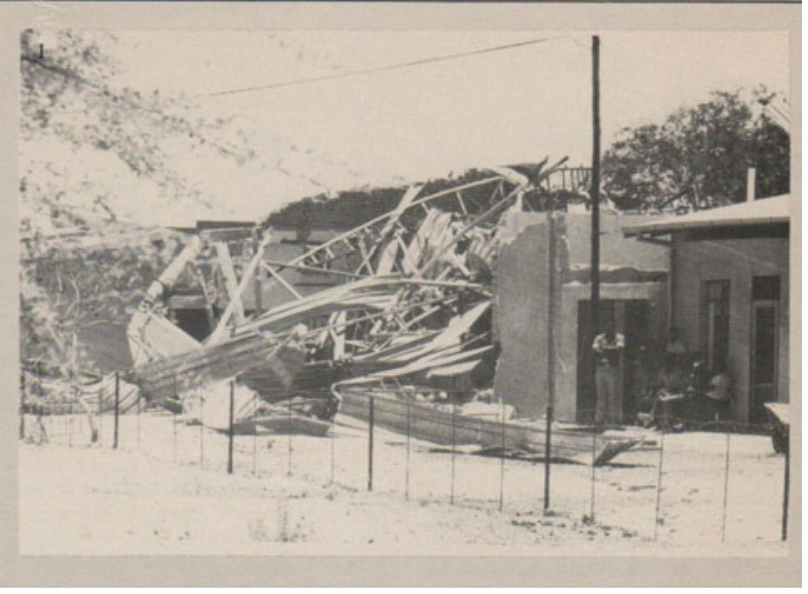

Figure 15: The remains of the printing offices after the second bomb blast outside Onandjokwe hospital in 1980. Source: Missionsnytt, 1980 [Missionary News].

orders'. ${ }^{141}$ The weak boundaries between healthcare and violence that were inbuilt in the South African war apparatus, together with their inadequate regard for human rights and international agreements coalesced into a disrespect for healthcare facilities. They may have considered Onandjokwe hospital as part of the SWAPO/PLAN war infrastructure, just as Oshakati hospital was a part their own. It seems important to stress that nothing indicates that Onandjokwe hospital actually was part of a warfare organisation. The fact that wounded PLAN soldiers came for help is, in the light of international agreements, not an argument for that. The hospital served many of those who worked for a Namibian state.

\section{Epilogue}

In 1988, diplomatic endeavors put an end to the border war. The South African military quickly abandoned Ovambo after military operations came to halt. Two years later Namibia put itself on the African map as an independent state under the diplomatic leadership of the former Finnish president Martti Ahtisari. The new Namibian government took on the arduous task of renovating, refurbishing and reorganising the apartheid healthcare system they took over at independence. The new system was based on the WHO primary healthcare principle and articulated the ambition to provide 'Health for all Namibians by the year 2000'. ${ }^{142}$ During the first years of independence the Ministry of Health and Social Services closed down superfluous hospitals, especially those that represented the double provision based on race in the southern area. Other hospitals were renovated, reconstructed and refurbished in order to modernise existing services and create a hierarchical system of referral hospitals. Many of them were old missionary hospitals or clinics, especially in the north. A total replacement of the Engela hospital was financed

${ }^{141}$ Paul Hirst, Space and Power Politics, War and Architecture (Cambridge: Polity Press, 2005), 54.

142 MoHSS, Towards Acheiving Health and Social Well Being for all Namibians. A Policy Framework (Windhoek: Ministry of Health and Social Services, 1998), 3. 
by the Finnish state. The three hospitals Okahao, Tsandi and Outapi were adapted to the district level. Clinics and health centres of various sizes were provided so that all Namibians would have access to primary care within a 3-hour walking distance. Maternal and child healthcare provision had high priority. ${ }^{143}$

In the mid-1990s, renovation works started in the Intermediate Hospital Oshakati that was to replace the whole hospital. This work was finished just over ten years later. Onandjokwe hospital was now run by the Evangelical Lutheran Church of Namibia and was also renovated. ${ }^{144}$ It celebrated its 100 -year anniversary in 2011 . The adobe inpatient wards have now been torn down but the hospital will be renovated with financial support from, among others, the Finnish missionary society and the Finnish state. ${ }^{145}$

\section{Conclusions}

In different colonies in Africa, various types of healthcare system appeared in which secular and missionary medicine cooperated and complemented each other. ${ }^{146}$ South African and missionary interests gave shape to the healthcare distribution in the northern part of Namibia. They both had other embedded agendas besides the tangible one, the healthcare provision as such. The absence of governmental hospitals was linked to apartheid interest in that area as primarily a labour reserve. Missionaries provided the healthcare that fell outside the governmental examinations and immunisations accompanying the recruitment of contract labourers. South Africa's neglect of local people's healthcare needs allowed the Finnish missionaries a free hand to establish facilities according to their agenda. To them, the evangelisation was the prime goal, while healthcare was a means of attracting people to the missionary stations. Health facilities accompanied the spatial proliferation of evangelisation efforts rather than the health needs of the people. For instance, Onandjokwe hospital was constructed where the Ondonga king had allowed the missionaries to settle. However, the prospect of access to healthcare may have encouraged local leaders' acceptance of the missionary presence.

When South Africa chose to engage directly in medical practice in Ovambo, political considerations overshadowed local health concerns. Politics and medicine were mixed in colonial practices. ${ }^{147}$ When the apartheid hospital was constructed in Oshakati it was linked to these intertwined colonial and clandestine medico-political discourses. The healthcare provisions stipulated in the Odendaal Plan, including the construction of the Oshakati hospital, were strategic advances on an international scene. The hospital was constructed after the majority of African colonies had been given independence. An obsolete medical colonial-spatial order was maintained by the South Africans in order to save their faltering system. The unequal apartheid health system was introduced into northern Namibia by the implementation of the homeland structure, as in South Africa. At that time the Finnish missionaries tended not to criticise apartheid because of the governmental funding of the missionary healthcare system and their control of

\footnotetext{
143 Interview with MoHSS officer.

144 From the author's own observations.

145 Fotnotes Martinus Foundation Homepage, http://www.martinus.fi/?sid=22, accessed 18 August 2013.

146 Jennings, op. cit. (note 2).

147 Michael A. Osborne and Richard F. Fogarty, 'Views Form the Periphery: Discourses of Race and Place in French Military Medicine', History and Philosophy of the Life Sciences 25, 3 (2003), 363-89. Patricia M.C. Lorcin, 'Imperialism, Colonial Identity, and Race in Algeria, 1830-70. The Role of French Medical Corps', Isis, 90, 4 (1999), 652-79. Good, op. cit. (note 48), 4-5.
} 
missionaries' residence permits. This caution may have contributed to the prolongation of old-fashioned curative health services based on hospital care, even though that was not the aim. Primary healthcare was an ambition in many independent African countries and was implemented more or less successfully. ${ }^{148}$ This was the path the government in independent Namibia followed later.

The missionaries worked according to their view of the best interests of the local people and in close cooperation with them. This interaction eventually created the final cleavage between the Finnish missionaries and the South African government. The two hospitals became involved on opposite sides in the war. They did not just receive patients produced by the war, they also became war scenes. Oshakati hospital was staffed by the military and cooperated with the neighbouring base while Onandjokwe hospital was subject to military violence and control. The international focus on Namibia probably prevented South Africa expelling Finnish missionaries and pursuing aggressive attacks on healthcare facilities as they did in newly independent Mozambique, where hospitals and clinics were the targets of the South Africans' deliberate military assaults. ${ }^{149}$

From the 1970s, governmental health service provisions in the north were influenced by South African military and strategic considerations. Healthcare resources were generously allocated to certain projects of strategic value to South Africa in order to win the hearts and minds of local people. Similar strategies were pursued by Portugal's colonial administration in Guinea-Bissau where the policy of winning the hearts and minds resulted in an expansion in, among other things, the healthcare infrastructure. ${ }^{150}$ The Finnish missionaries were redefined as the enemy in the South African ventures and were therefore excluded and disadvantaged in South Africa's allocations of medical resources.

Medical missions and missionary stations formed part of a colonial political network that spread widely into the hinterlands of the vast colonies, constituting a vanguard in colonial expansion and biomedical medicine. ${ }^{151}$ The Finnish missionary expansion, affected and restructured by South African apartheid and military considerations, contributed to a large extent to the future health geography of northern Namibia. Presentday hospitals and health centres in the area are located in places where the missionaries opened their hospitals and dispensaries. Many of those places are small towns or villages today. Oshakati, which did not exist before the hospital was constructed, is now the bustling centre of the region. Through Oniipa runs a long street with vendors, cuca shops, ${ }^{152}$ markets and panel beaters' workshops where cars and trucks stop to drop off hitchhikers at the Onandjokwe hospital.

\footnotetext{
148 Bloom, op. cit. (note 88); McPake, op. cit. (note 60); Cliff and Noormahomed, op. cit. (note 134).

149 Cliff and Noormahomed, op. cit. (note 134), 717-18.

150 Peter Karibe Mendy, 'Portugal's Civilizing Mission in Colonial Guinea-Bissau: Rhetoric and Reality', International Journal of African Historical Studies, 36, 1 (2003), 35-58: 47, 49.

151 Good, op. cit. (note 48), 5 .

152 A cuca shop is a small bar where food and beer are sold.
} 